\title{
Assessment of essential elements and chemical contaminants in thirteen fish species from the Bay Aratu, Bahia, Brasil
}

\author{
E. Silva ${ }^{*}$, Z. C. V. Viana ${ }^{b}$, N. F. A. Souza ${ }^{c}$, M. G. A. Korn ${ }^{d}$ and V. L. C. S. Santos ${ }^{d}$ \\ ${ }^{a}$ Unidade Acadêmica de Ciências Biológicas, Universidade Federal de Campina Grande - UFCG, \\ Av. Universitária, s/n, CP 61, CEP 58708-110, Patos, PB, Brazil \\ bInstituto de Ciências da Saúde, Universidade Federal da Bahia - UFBA, \\ Av. Reitor Miguel Calmon, s/n, Vale do Canela, CEP 40110-100, Salvador, BA, Brazil \\ 'Instituto de Geociências, Universidade Federal da Bahia - UFBA, Rua Barão de Jeremoabo, s/n, \\ Ondina, CEP 40170-120, Salvador, BA, Brazil \\ 'Instituto de Química, Universidade Federal da Bahia - UFBA, Rua Barão de Jeremoabo, s/n, \\ Ondina, CEP 40170-115, Salvador, Bahia, Brazil \\ *e-mail: edevaldos@yahoo.com.br
}

Received: February 9, 2015 - Accepted: August 12, 2015 - Distributed: November 30, 2016

(With 4 figures)

\begin{abstract}
Concentrations of ten elements $(\mathrm{Cd}, \mathrm{Cr}, \mathrm{Cu}, \mathrm{Fe}, \mathrm{Ni}, \mathrm{Pb}, \mathrm{Se}, \mathrm{Sr}, \mathrm{V}$ and $\mathrm{Zn}$ ) were determinate in muscle tissues of 13 fish species from Aratu Bay, Bahia, Brazil by inductively coupled plasma optical emission spectrometry. The accuracy and precision of our results were checked by using two certified reference materials: BCR-422 cod muscle and SRM 1566b oyster tissue. The average trace element concentrations in the fish species varied in the following ranges, in $\mu \mathrm{g} \mathrm{g}^{-1}$ : 0.03-0.8 for $\mathrm{Cr}$; 2.0-33.7 for $\mathrm{Cu}, 2.4-135.1$ for Fe, 1.6-25.6 for Se; 1.6-35.1 for Sr; and 2.8-40.5 for Zn. The Diaptereus rhombeus (carapeba) specie presented the highest concentrations of $\mathrm{Se}, \mathrm{Cu}$ and Fe. Chromium and Se were present at levels above the limit of tolerance allowed by the National Agency of Sanitary Vigilance (ANVISA). The results were also evaluated using the multivariate analysis techniques: principal component analysis (PCA) and hierarchical cluster analysis (HCA).
\end{abstract}

Keywords: seafood, chromium, selenium, composition, ICP OES.

\section{Avaliação de elementos químicos essenciais e contaminantes em treze espécies de peixes da Baía de Aratu, Bahia, Brasil}

\section{Resumo}

Foram determinadas as concentrações de dez elementos ( $\mathrm{Cd}, \mathrm{Cr}, \mathrm{Cu}, \mathrm{Fe}, \mathrm{Ni}, \mathrm{Pb}, \mathrm{Se}, \mathrm{Sr}, \mathrm{V}$ and $\mathrm{Zn}$ ) em tecidos de músculos de treze espécies de peixes da Baía de Aratu, Bahia, Brasil, utilizando a espectrometria de emissão ótica com plasma indutivamente acoplado. A precisão e exatidão dos resultados foram analisadas utilizando dois materiais de referência certificada: BCR-422 cod muscle e o SRM 1566b oyster tissue. A concentração média dos elementos traço nas espécies de peixes variaram nas seguintes faixas, em $\mu \mathrm{g} \mathrm{g}^{-1}$ : $\mathrm{Cr}=0,03-0,8 ; \mathrm{Cu}=2,0-33,7, \mathrm{Fe}=2,4-135,1, \mathrm{Se}=1,6-25,6$; $\mathrm{Sr}=1,6-35,1 ; \mathrm{Zn}=2.8-40.5$. A espécie Diaptereus rhombeus (carapeba) apresentou as maiores concentrações de $\mathrm{Se}, \mathrm{Cu}$ e Fe. Cromo e Se apresentaram níveis acima do limite de tolerância estabelecido pela Agência Nacional de Vigilância Sanitária (ANVISA). Os resultados ainda foram avaliados usando técnicas de análises multivariadas: análise de componente principal (PCA) e análise de agrupamento hierárquico (HCA).

Palavras-chave: fruto do mar, cromo, selênio, composição, ICP OES.

\section{Introduction}

Food from marine ecosystems, especially fish, is highly valued because of its large concentration of nutrients, with high quality protein (Viana et al., 2013) and contain omega series polyunsaturated fatty acids (Alkan et al., 2016). These ecosystems are currently undergoing transformations because of the increased presence of chemical elements due to rapidly growing industrial development and its impact. Some of these elements are beneficial in small quantities, while others can cause serious health problems even in small amounts (Chiba et al., 2011a).

The determination of trace elements in food, such as fish, is of great importance in assessing both their nutritional 
quality and also the risk of environmental contamination (Conti et al., 2012). Elements such as lead and cadmium are toxic even at low concentrations and marine organisms can accumulate high concentrations of these chemicals (Copat et al., 2013), while iron, copper, zinc and manganese are essential metals because they play an important role in biological systems. Essential elements can also produce toxic effects at high concentrations. The metal content in water inhabited by fish is reflected by the concentration of metal in their muscles (Chiba et al., 2011b).

In Brazil, the ANVISA, in its Decree n ${ }^{\circ} 55871$ (ANVISA, 1965), defines the maximum concentration values of tolerance for 10 metals in foods, among them are the metals $\mathrm{Cd}, \mathrm{Cr}$, $\mathrm{Cu}, \mathrm{Ni}, \mathrm{Pb}$ and $\mathrm{Zn}$, in addition nonmetal Se. According to these values, some essential metals have higher tolerance limits, such as $\mathrm{Zn}\left(50.00 \mathrm{mg} \mathrm{g}^{-1}\right)$ and $\mathrm{Cu}\left(50.00 \mathrm{mg} \mathrm{g}^{-1}\right)$. However, the ingestion of food contaminated by potentially toxic chemicals is tolerated at low concentrations, such as $\mathrm{Cr}\left(0.10 \mathrm{mg} \mathrm{g}^{-1}\right), \mathrm{Cd}\left(1.00 \mathrm{mg} \mathrm{g}^{-1}\right), \mathrm{Pb}\left(2.00 \mathrm{mg} \mathrm{g}^{-1}\right)$ and $\mathrm{Se}\left(0.30 \mathrm{mg} \mathrm{g}^{-1}\right)$.

Aratu Bay $\left(12^{\circ} 48^{\prime} \mathrm{S} ; 38^{\circ} 28^{\prime} \mathrm{W}\right)$ is a shallow estuarine bay of 1215 ha with a heterogeneous shoreline, varying from mixed substrates of rock, gravel, sand and mud bordered by upland forest, to uniform tidal mud-flats bordered by a mixed mangrove community. An industrial complex was established in the area surrounding Aratu Bay in the late 1960s, and it has received both domestic discharges and industrial effluents since that time. A large variety of manufacturing enterprises, primarily metallurgic, have been delivering their wastes directly to the surrounding areas, with only primary treatment which is not effective. The nature of these effluents is complex, containing a variety of both organic and inorganic wastes, including heavy metals.

Thus, despite the Aratu Bay have a high environmental commitment (Lessa et al., 2009) and ecological importance, there is a lack of scientific information concerning metal concentration in fish species to evaluate the potential adverse environmental effects of contaminants have been done in Aratu Bay.

For this reason, our objective from this study was to determine the levels of some trace elements in some economically important fish species collected in Aratu Bay for the purpose of providing information that may help improve the quality of life of the populations that consume this food.

\section{Material and Methods}

\subsection{Sampling}

Samples were collected from thirteen species of fish in the Bay of Aratu (Figure 1). The species and their common names were: Achirus lineatus, Linnaeus, 1758 (tapa); Archosargus rhomboidalis, Linnaeus,

$38^{\circ} 45^{\prime}$

$38^{\circ} 30^{\prime}$

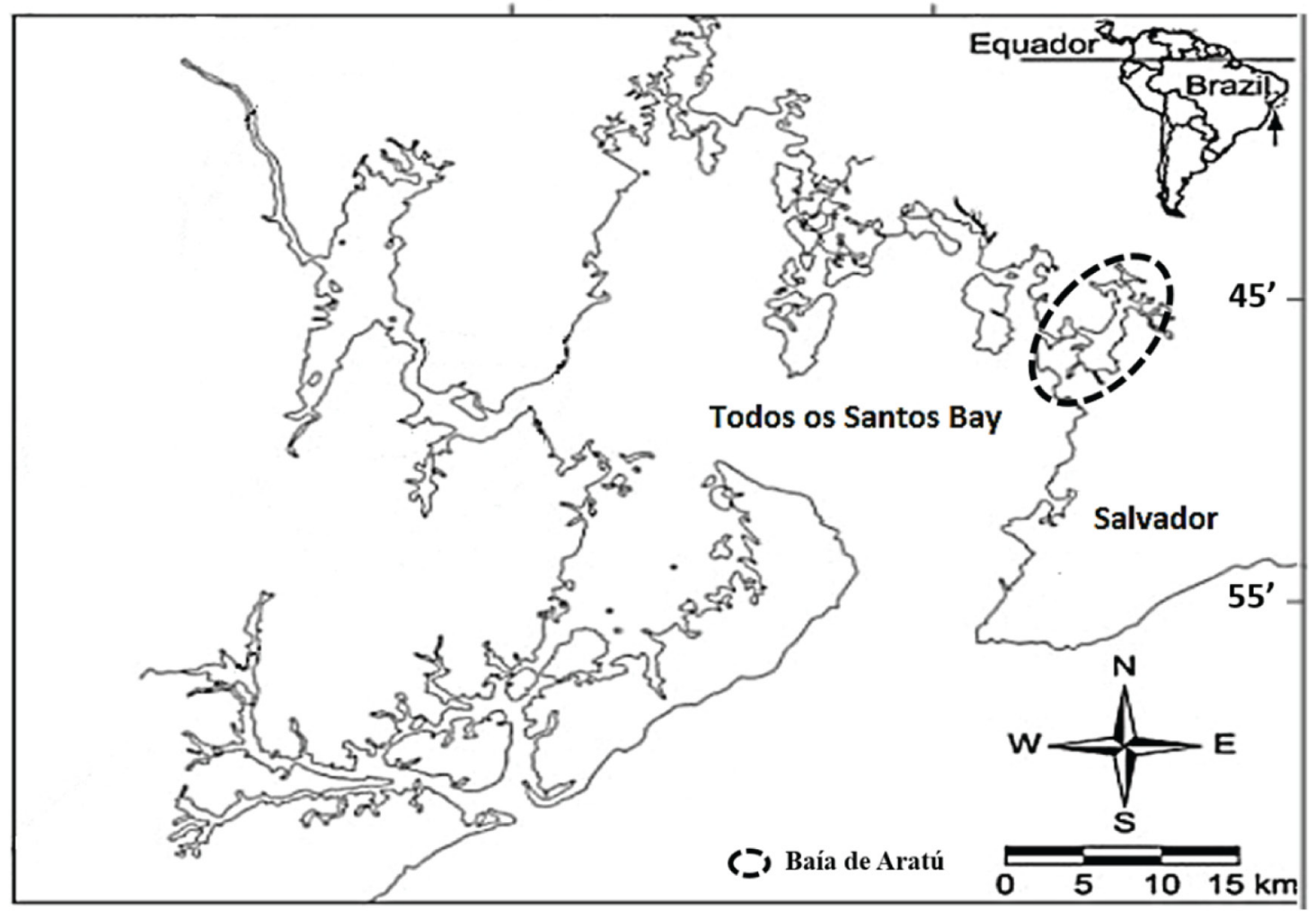

Figure 1. Location of Aratu Bay, state of Bahia (BA), Brazil. 
1758 (sargo); Caranx latus, Agassiz, 1829 (guarajuba); Chloroscombrus chrysurus, Linnaeus, 1766 (palombeta); Cynoscion leiarchus, Cuvier, 1830 (pescada branca); Diapterus rhombeus, Cuvier, 1829 (carapeba); Lutjanus synagris, Linnaeus, 1758, (ariacó); Micropogonias furniere, Linnaeus, 1766 (corvina); Oligoplites palometa, Cuvier, 1832 (guaibira); Paralichthys brasiliensis, Ranzani, 1842 (linguado preto); Pomadasys corvinaeformis, Steindachner, 1868 (cocoroca legítima); Scomberomorus brasiliensis Collette, Russo and Zavala-Camin, 1978 (sororoca); Selene vomer, Linnaeus, 1758 (galo) (Araújo et al., 2004). These species were collected in one trawl sampling, placed in plastic bags and sent to the laboratory under cooling. The study encompassed dorsal muscles in fish.

\subsection{Briefing of samples}

Three units of each species were captured, and for each species was carried out three analyzes of each sample. Less than $48 \mathrm{~h}$ after sampling, the collected fish were subjected to biometrics and then filleted individually to obtain muscle samples, which were homogenized, freeze-dried, sieved (particles $=149 \mu \mathrm{m} 100 \mathrm{mesh}$ ). Approximately $0.2 \mathrm{~g}$ of each muscle sample from each species was placed in a Teflon digester to which $2 \mathrm{~mL} \mathrm{HNO}_{3} 65 \%$ $(\mathrm{v} / \mathrm{v})$ and $2 \mathrm{~mL}$ of deionized water were added, and the digester was capped, placed in a stainless steel container and sealed with a screw cap. The sample was allowed to stand for four hours, initiating the decomposition of the organic matter. The samples were dried at $120{ }^{\circ} \mathrm{C}$ for $14 \mathrm{~h}$ to supplement digestion (Viana et al., 2012). Three blanks were used for each sample digestion batch. The digested samples were quantitatively transferred to $10 \mathrm{~mL}$ volumetric flasks that were augmented with MILLI-Q ${ }^{\circledR}$ ultrapure water.

\subsection{Chemical analysis}

An inductively coupled plasma optical emission spectrometer with axially viewed configuration (VISTA PRO, Varian, Mulgrave, Australia) equipped with solid state detector, cyclonic spray chamber, and concentric nebulizer was employed for $\mathrm{Cd}, \mathrm{Cr}, \mathrm{Cu}, \mathrm{Fe}, \mathrm{Ni}, \mathrm{Pb}, \mathrm{Se}$, $\mathrm{Sr}, \mathrm{V}$ and $\mathrm{Zn}$ determinations. The operating conditions (Table 1) were optimized in order to obtain both plasma robustness and greater signal-to-background ratios, using $\mathrm{MgII} / \mathrm{MgI}$ intensity ratio. Table 1 lists the experimental conditions followed.

The reference solutions used to obtain the calibration curves were prepared from a stock solution containing $1000 \mathrm{mg} \mathrm{L}^{-1}$ of each chemical element studied. The blanks and reference solutions were analyzed using the same method that was applied to the samples. The concentrations were expressed in $\mu \mathrm{g} \mathrm{g}^{-1}$ dry weight.

\subsection{Quality control of trace elements analysis}

The precision and accuracy of the method were validated by triplicate analysis of certified reference materials (CRM) from the National Research Council
Canada (BCR-422, cod muscle) and standard reference materials (SRM) from the National Bureau of Standards Certificate of Analysis, NIST (SRM-1566b, oyster tissue) using the same analytical procedure as was applied to the samples.

\subsection{Multivariate analysis}

Principal component analysis (PCA) permits two and three dimensional graphical representations of higher order dimensional spaces. Here an eight dimensional space for which each element concentration is represented by a coordinate axis is projected onto two dimensional graphs so that the statistical distribution of the data can be visualized. Since statistical information is lost when eight dimensional space is projected onto two dimensional graphs a complementary hierarchical cluster analysis (HCA) was performed. Both analysis has been used in environmental studies involving metals (Anju and Banerjee, 2012).

\section{Results and Discussion}

\subsection{Validation of the analytical method}

The limits of detection (LOD) and the limits of quantification (LOQ) were calculated based on the standard deviation of 20 readings obtained for the analytical blanks and the slopes of the analytical curves (LOD $=3 \sigma /$ slope and LOQ $=10 \sigma /$ slope). Their values were $\left(\mu \mathrm{g} \mathrm{kg}^{-1}\right): \mathrm{Ni}=6.7-23.0 ; \mathrm{Se}=4.1-14.0, \mathrm{Zn}=2.9-10$; $\mathrm{Cu}=6.6-21 ; \mathrm{Fe}=5.0-17.0 ; \mathrm{Cr}=3.9-13.3 ; \mathrm{Cd}=0.4-1.2$; $\mathrm{Pb}=15.9-54.0 ; \mathrm{V}=3.0-10.2$.

The experimental results for trace elements in the certified reference materials (CRM) from the NRCC (DORM-2, DOLT-2 and TORT-2) presented good agreement

Table 1. Instrumental parameters for elements determination using axial ICP OES.

\begin{tabular}{|c|c|}
\hline Parameter & Value \\
\hline RF incident power (W) & 1300 \\
\hline $\begin{array}{l}\text { Plasma gas flow rate } \\
\left(\mathrm{L} \min ^{-1}\right)\end{array}$ & 15 \\
\hline $\begin{array}{l}\text { Auxiliary gas flow rate } \\
\left(\mathrm{L} \mathrm{min}^{-1}\right)\end{array}$ & 1.5 \\
\hline $\begin{array}{l}\text { Nebulizer argon gas flow } \\
\text { rate }\left(\mathrm{L} \mathrm{min}^{-1}\right)\end{array}$ & 0.70 \\
\hline Replicateread time (s) & 1 \\
\hline $\begin{array}{l}\text { Instrumentstabilizationdelay } \\
\text { (s) }\end{array}$ & 15 \\
\hline 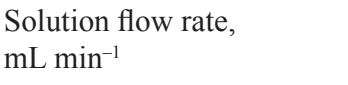 & 0.8 \\
\hline \multirow[t]{4}{*}{ Spectrallines (nm) } & $\mathrm{Cd}$ (I) $202.032 \mathrm{Cu}$ (I) 422.673 \\
\hline & $\mathrm{Cr}$ (II) $267.716 \mathrm{Fe}$ (II) 238.204 \\
\hline & $\mathrm{Ni}$ (II) $231.604 \mathrm{~Pb}$ (II) 220.353 \\
\hline & $\begin{array}{l}\text { Se(I) 196.026 Sr (I) 407.711 } \\
\text { V(II) 292.401 Zn(I) 213.857 }\end{array}$ \\
\hline
\end{tabular}

(I) atomic emission line; (II) ionic emission line. 
with the certified values. The recovery rates were between $90 \%$ and $95 \%$. The relative standard deviation ( $\mathrm{SD} /$ mean) for each reference sample was lower than $10 \%$, showing that the analytical procedure was suitable. According to these results, we can conclude that the analytical method was accurate and precise for trace element determination in biological tissues.

\subsection{Determinations of the elements contents of fish muscles}

The results of the determination of five chemical elements in muscle samples from thirteen different species of fish are presented in Table 2. The elements $\mathrm{Cr}, \mathrm{Cu}, \mathrm{Fe}$, $\mathrm{Se}$, and $\mathrm{Zn}$ were detected in all the samples analyzed. For all species except $C$. latus and $P$. brasiliensis, the content of $\mathrm{Cd}, \mathrm{Pb}, \mathrm{V}$ and $\mathrm{Ni}$ were below the LOQ of the method used here. In general, only small quantities of $\mathrm{Ni}$ are detected in fish tissue. In C. latus and P. brasiliensis, nickel was detected at $0.3 \mu \mathrm{g} \mathrm{g}^{-1}$ and $0.4 \mu \mathrm{g} \mathrm{g} \mathrm{g}^{-1}$ respectively. The low concentrations of $\mathrm{Cd}, \mathrm{Pb}, \mathrm{V}$ and $\mathrm{Ni}$ found in this study are similar to reports by other researchers (Tuzen, 2009; Meche et al., 2010).

The minimum $\left(1.6 \mu \mathrm{g} \mathrm{g}^{-1}\right)$ and maximum $\left(25.6 \mu \mathrm{g} \mathrm{g}^{-1}\right)$ selenium concentrations were found in C. chrysurus and D. rhombeus, respectively (Table 2). Although have observed higher selenium content in Condat of Gallia, Ohio, USA, the majority of authors have reported lower levels of this element in fish than those detected in this work (Tuzen, 2009; Viana et al., 2012; Olmedo et al., 2013). Selenium is needed for various functional properties of the human body, mainly in the nervous system (Niedzielski et al., 2016), and it participates in the detoxification of the body (Sørmo et al., 2011). However, human intake of selenium in high concentrations can be toxic (Tuzen, 2009) and cause selenose, with gastrointestinal problems, skin rash and nervous system abnormalities (Goldhaber, 2003).
The highest content of zinc $\left(40.5 \mu \mathrm{g} \mathrm{g}^{-1}\right)$ was observed in the P. brasiliensis, while the value in L. synagris was below the LOQ $\left(<0.010 \mu \mathrm{g} \mathrm{g}^{-1}\right.$; Table 2$)$. The fish investigated for these elements in other works had similar levels of $\mathrm{Zn}$ compared to the higher values found in this study (Omar et al., 2014). Fish is an excellent source of zinc, a trace element in biological systems necessary to participate in the metabolism of carbohydrates, lipids, proteins and nucleic acids. It also stimulates the activity of several enzymes. The excess zinc in the human diet can cause toxic effects on the immune system, reducing the stimulation responses of lymphocytes and alterations in cholesterol metabolism, decreased HDL levels in healthy people (Goldhaber, 2003). Its deficiency in the body can lead to loss of appetite, growth retardation, and skin and immunological problems (Tuzen, 2009).

The smallest concentration of copper $\left(2.0 \mu \mathrm{g} \mathrm{g}^{-1}\right)$ was in L. synagris, and the largest concentration $\left(33.7 \mu \mathrm{g} \mathrm{g}^{-1}\right)$ was in D. rhombeus (Table 2). There have been several studies in different locations that indicate smilar levels of $\mathrm{Cu}$ in fish (Mendil et al., 2010; Alkan et al., 2016) and others seafood (Silva et al., 2016). Copper is essential in metabolic processes, but is an important environmental contaminant (Hauser-Davis et al., 2014).

Iron showed the lowest concentration $\left(2.4 \mu \mathrm{g} \mathrm{g}^{-1}\right)$ in $P$. brasiliensis and the highest $\left(135.1 \mu \mathrm{g} \mathrm{g}^{-1}\right)$ in D. rhombeus (Table 2). Studies on the distribution of metals in fish emphasize that the variations obtained in the absorption of $\mathrm{Fe}$ in different species should be evaluated because Fe plays an important role in biological systems (Carvalho et al., 2000).

The highest concentration $\left(0.8 \mu \mathrm{g} \mathrm{g}^{-1}\right)$ of chromium was detected in $P$. corvinaeformis. Studies with several other species of fish of commercial importance in Sao Paulo, Brazil (Morgano et al., 2014) and in Catania, Italy (Copat et al., 2013) reported lower values of this element. Chromium is a metal porphyrin present in oil.

Table 2. Concentrations (average $\pm \mathrm{ts}$; $95 \%$ confidence level) for fish species obtained by ICP OES (dry weight).

\begin{tabular}{lccccc}
\hline \multicolumn{1}{c}{ Fish species } & $\mathbf{C r}$ & $\mathbf{C u}$ & $\mathbf{F e}$ & $\mathbf{S e}$ & $\mathbf{Z n}$ \\
\hline Achirus lineatus & $0.4 \pm 0.1$ & $25.3 \pm 0.1$ & $38.6 \pm 1.1$ & $3.4 \pm 0.3$ & $16.8 \pm 3.3$ \\
Archosargus rhomboidalis & $0.030 \pm 0.001$ & $9.4 \pm 0.3$ & $29.2 \pm 0.6$ & $2.8 \pm 0.1$ & $12.6 \pm 1.7$ \\
Caranx latus & $0.5 \pm 0.1$ & $7.2 \pm 0.1$ & $39.8 \pm 12.7$ & $1.8 \pm 0.2$ & $14.5 \pm 1.2$ \\
Chloroscombrus chrysurus & $0.20 \pm 0.03$ & $8.2 \pm 0.1$ & $51.1 \pm 1.2$ & $1.6 \pm 0.1$ & $32.5 \pm 4.9$ \\
Cynoscion leiarchus & $<\mathrm{LOQ}$ & $5.8 \pm 0.4$ & $21.7 \pm 0.4$ & $1.8 \pm 0.4$ & $6.3 \pm 0.4$ \\
Diapterus rhombeus & $0.4 \pm 0.1$ & $33.7 \pm 0.2$ & $135.1 \pm 0.1$ & $25.6 \pm 0.9$ & $39.4 \pm 0.4$ \\
Lutjanus synagris & $0.20 \pm 0.01$ & $2.0 \pm 0.2$ & $10.9 \pm 0.3$ & $1.8 \pm 0.1$ & $<\mathrm{LOQ}$ \\
Micropogonias furniere & $0.5 \pm 0.1$ & $3.3 \pm 0.2$ & $38.5 \pm 1.2$ & $4.4 \pm 0.1$ & $2.8 \pm 0.6$ \\
Oligoplites palometa & $0.50 \pm 0.01$ & $9.2 \pm 0.1$ & $38.9 \pm 0.1$ & $2.6 \pm 0.2$ & $24.7 \pm 0.8$ \\
Paralichthys brasiliensis & $0.60 \pm 0.01$ & $17.2 \pm 0.1$ & $2.4 \pm 0.4$ & $1.8 \pm 0.1$ & $40.5 \pm 0.5$ \\
Pomadasys corvinaeformis & $0.80 \pm 0.01$ & $7.2 \pm 2.6$ & $39.7 \pm 5.8$ & $3.4 \pm 0.8$ & $24.3 \pm 0.2$ \\
Scomberomorus brasiliensis & $0.50 \pm 0.01$ & $7.4 \pm 0.2$ & $21.1 \pm 0.2$ & $2.5 \pm 0.2$ & $26.1 \pm 0.2$ \\
Selene vomer & $0.03 \pm 0.01$ & $6.4 \pm 0.8$ & $61.8 \pm 4.7$ & $2.1 \pm 0.1$ & $2.8 \pm 0.2$ \\
\hline
\end{tabular}

Three specimens were analyzed by species, each of which was performed in triplicate. $<$ LOQ: lower limit of quantification. 
The investigation of $\mathrm{Cr}$ in environmental samples may help in evaluating contamination sources. However, $\mathrm{Cr}^{3+}$ appears to be a cofactor for proteins of low molecular weight. The presence of $\mathrm{Cr}$ in the diet is important for lipid metabolism and insulin action (Mendil and Uluozlu, 2007).

In this study, variations of the concentrations of trace elements found in the muscle of different fish species were of the same order of magnitude as those reported in previous studies with the same species (Mendil and Uluozlu, 2007; Türkmen et al., 2009). This can be explained by the accumulation of different chemical elements in the dorsal and ventral muscles of the same fish (Ling et al., 2009). Furthermore, there is variation in the ages, sizes, habitats, and metabolic activities of the fish, resulting in differences between species (Uysal et al., 2009). However, the contents of $\mathrm{Se}$ and $\mathrm{Cr}$ were above those permitted in food by Brazilian legislation (ANVISA, 1965).

\subsection{Data analysis}

In this research, PCA and cluster analysis were applied to the total metal content (Table 2). PCA has been applied in this way for the evaluation and classification of analytical results (Chaves et al., 2010; Nascimento et al., 2010; Bentlin et al., 2011; Yap et al., 2010; Santos et al., 2010). The applied PCA resulted in two significant PCs ( $\mathrm{PC} 1$ and $\mathrm{PC} 2$ ), accounting for $84 \%$ of the total variance of the presented data. The scores and loadings of the first two PCs (PC1 and PC2) are plotted in Figure 2.

From the loadings of the variables in the first principal components, $D$. rhombeus stands out from the others with a score of 5.13. A second group formed by A. lineatus e $P$. brasiliensis were the dominant features in the positive part of the first principal component, whereas L. synagris was the main feature in the negative part of this component. For the second principal component (PC2) can be considered as an index that compares $\mathrm{Cr}$ and $\mathrm{Zn}$ (positive signs) with $\mathrm{Cu}, \mathrm{Fe}$ and $\mathrm{Se}$ (negative signals). $P$. brasiliensis and P. corvinaeformis are the dominant features, due higher $\mathrm{Cr}$ and $\mathrm{Zn}$ concentrations in Figure 3.

HCA (hierarchical cluster analysis) is a technique often used in combination with PCA to study the structure of a data set. HCA is an unsupervised procedure that allows one to map the multidimensional space of variables to a two-dimensional tree called a "dendrogram" constructed on the basis of the similarity (or distance) between samples. Thus, CA was applied, in the present case, to the autoscaled data to achieve this objective. The similarities between samples were calculated on the basis of the squared Euclidean distance, whereas the Ward method (a hierarchical agglomerative system) was used to establish the clusters (Yap et al., 2010). The dendrogram of cluster analysis to the scores of the first two principal components are presented in Figure 4.

In this figure, the clusters obtained for the $D$. rhombeus were not correlated with the other species, confirming the conclusion previously obtained by PCA. This fish specie has higher concentration of $\mathrm{Cu}, \mathrm{Fe}$ and $\mathrm{Se}$.

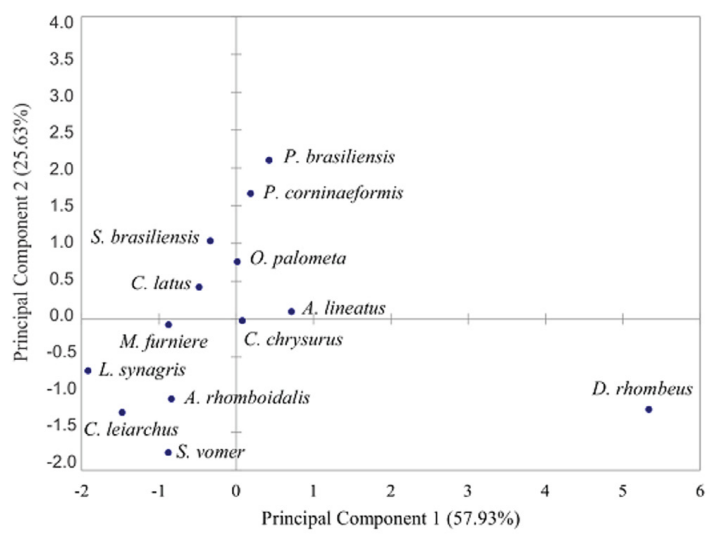

Figure 2. Principal Component Analysis (PC1 e PC2) the species of fish.

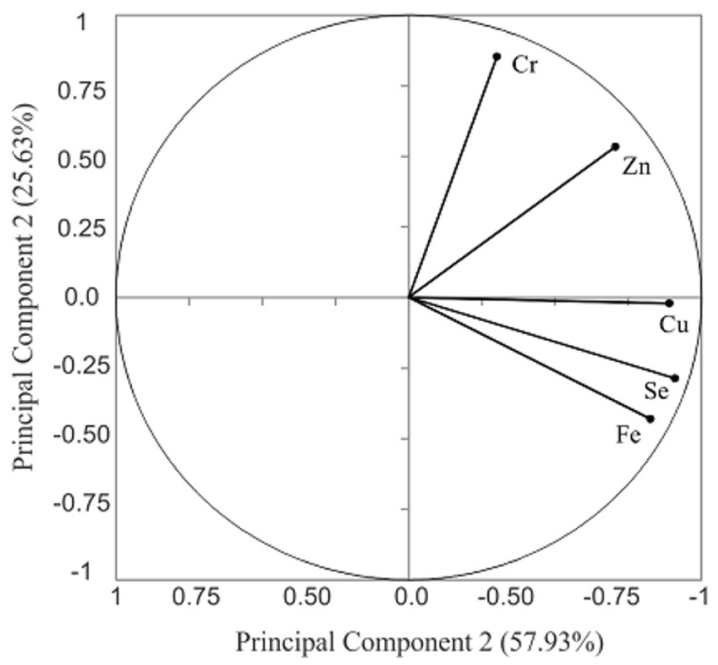

Figure 3. Principal Component Analysis (PC1 e PC2) for chemicals.

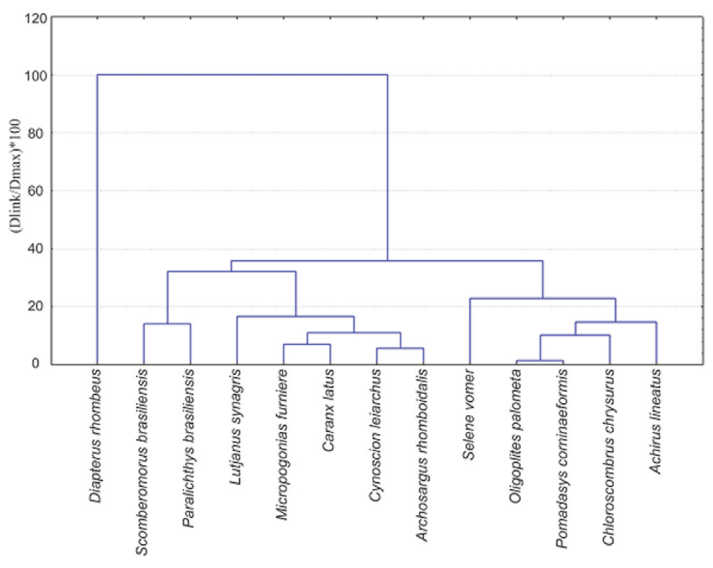

Figure 4. Dendrogram of cluster analysis to the scores of the first two principal components. 


\section{Conclusions}

Despite the port activities in Aratu Bay, there is no evidence of $\mathrm{Cd}$ or $\mathrm{Pb}$ contamination in the time period studied. This area could be used for research on the development of baseline data for these elements concerning environmental studies and the biochemistry of fish. The elements $\mathrm{Zn}, \mathrm{Cu}$, Se and Fe exhibited similar behavior in terms of absorption for all species being the element $\mathrm{Cr}$ apart from the others. It can be concluded from the PCA and CA results that the $D$. rhombeus presented different behavior in the metals absorption.

\section{Acknowledgements}

The support of Fundação de Amparo a Pesquisa do Estado da Bahia (FAPESB), Conselho Nacional de Desenvolvimento Científico e Tecnológico (CNPq) and Coordenação de Aperfeiçoamento de Pessoal de Nível Superior (CAPES).

\section{References}

AGÊNCIA DE VIGILÂNCIA SANITÁRIA - ANVISA [viewed 19 March 2016]. Decreto $n^{\circ} 55871$, de 26 de março de 1965. Diário Oficial da União [online], Brasília, 9 abr. 1965. Available from: http://portal.anvisa.gov.br/wps/wcm/connect/414d248047 $458 \mathrm{a} 7 \mathrm{~d} 93 \mathrm{f} 3 \mathrm{~d} 73 \mathrm{fbc} 4 \mathrm{c} 6735 / \mathrm{DECRETO}+\mathrm{N} \% \mathrm{C} 2 \% \mathrm{BA}+55.871,+\mathrm{D}$ $\mathrm{E}+26+\mathrm{DE}+\mathrm{MAR} \% \mathrm{C} 3 \% 87 \mathrm{O}+\mathrm{DE}+1965 . \mathrm{pdf} ? \mathrm{MOD}=\mathrm{AJPERES}$

ALKAN, N., ALKAN, A., GEDIK, K. and FISHER, A., 2016. Assessment of metal concentrations in commercially important fish species in Black Sea. Toxicology and Industrial Health, vol. 32, no. 3, pp. 447-456. http://dx.doi.org/10.1177/0748233713502840. PMid:24193046.

ANJU, M. and BANERJEE, D.K., 2012. Multivariate statistical analysis of heavy metals in soils of a $\mathrm{Pb}-\mathrm{Zn}$ mining area, India. Environmental Monitoring and Assessment, vol. 184, no. 7, pp. 4191-4206. http://dx.doi.org/10.1007/s10661-011-2255-8. PMid:21818539.

ARAÚJO, M.E., TEIXEIRA, J.M.C. and OLIVEIRA, A.M.E., 2004. Peixes estuarinos marinhos do nordeste brasileiro: guia ilustrado. Fortaleza: Edições UFC. 260 p.

BENTLIN, F.R.S., PULGATI, F.H., DRESSLER, V.L. and POZEBON, D., 2011. Elemental analysis of wines from South America and their classification according to Country. Journal of the Brazilian Chemical Society, vol. 22, no. 2, pp. 327-336. http://dx.doi.org/10.1590/S0103-50532011000200019.

CARVALHO, C.E.V., FARIA, V.V., CAVALCANTE, M.P.O., GOMES, M.P. and REZENDE, C.E., 2000. Distribuição de metais pesados em peixes costeiros bentônicos da região de Macaé, R.J. Ecotoxicology and Environmental Restoration, vol. 3, pp. 64-68.

CHAVES, E.S., SANTOS, E.J., ARAUJO, R.G.O., OLIVEIRA, J.V., FRESCURA, V.L.A. and CURTIUS, A.J., 2010. Metals and phosphorus determination in vegetable seeds used in the production of biodiesel by ICP OES and ICP-MS. Microchemical Journal, vol. 96, no. 1, pp. 71-76. http://dx.doi.org/10.1016/j. microc.2010.01.021.

CHIBA, W.A.C.I., PASSERINI, M.D.I., BAIO, J.A.F., TORRES, J.C. and TUNDISI, J.G., 2011a. Seasonal study of contamination by metal in water and sediment in a sub-basin in the southeast of Brazil. Brazilian Journal of Biology $=$ Revista Brasileira de Biologia, vol. 71, no. 4, pp. 833-843. http://dx.doi.org/10.1590/ S1519-69842011000500004.

CHIBA, W.A.C., PASSERINI, M.D. and TUNDISI, J.G., 2011 b. Metal contamination in benthic macroinvertebrates in a sub-basin in the southeast of Brazil. Brazilian Journal of Biology $=$ Revista Brasileira de Biologia, vol. 71, no. 2, pp. 391-399. http://dx.doi. org/10.1590/S1519-69842011000300008. PMid:21755156.

CONTI, G.O., COPAT, C., LEDDA, C., FIORE, M., FALLICO, R., SCIACCA, S. and FERRANTE, M., 2012. Evaluation of heavy metals and polycyclic aromatic hydrocarbons (PAHs) in Mullus barbatusfrom Sicily Channel and risk-based consumption limits. Bulletin of Environmental Contamination and Toxicology, vol. 88, no. 6, pp. 946-950. http://dx.doi.org/10.1007/s00128-0120611-1. PMid:22450961.

COPAT, C., ARENA, G., FIORE, M., LEDDA, C., FALLICO, R., SCIACCA, S. and FERRANTE, M., 2013. Heavy metals concentrations in fish and shellfish from eastern Mediterranean Sea: consumption advisories. Food and Chemical Toxicology, vol. 53, pp. 33-37. http://dx.doi.org/10.1016/j.fct.2012.11.038. PMid:23211443.

GOLDHABER, S.B., 2003. Trace element risk assessment: essentiality vs. toxicity. Regulatory Toxicology and Pharmacology, vol. 38, no. 2, pp. 232-242. http://dx.doi.org/10.1016/S02732300(02)00020-X. PMid:14550763.

HAUSER-DAVIS, R.A., BASTOS, F.F., TUTON, B., CHÁVEZ ROCHA, R., SAINT' PIERRE, T., ZIOLLI, R.L. and ARRUDA, M.A., 2014. Bile and liver metallothionein behavior in copperexposed fish. Journal of Trace Elements in Medicine and Biology, vol. 28, no. 1, pp. 70-74. http://dx.doi.org/10.1016/j. jtemb.2013.09.003. PMid:24210855.

LESSA, G.C., CIRANO, M., GENZ, F., TANAJURA, C.A.S. and SILVA, R.R., 2009. Oceanografia física. In: V. HATJE and J.B. ANDRADE, eds. Baía de Todos os Santos: aspectos oceanográficos. Salvador: EDUFBA, pp. 67-119.

LING, M.P., HSU, H.T., SHIE, R.H., WU, C.C. and HONG, Y.S., 2009. Health risk of consuming heavy metals in farmed tilapia in central Taiwan. Bulletin of Environmental Contamination and Toxicology, vol. 83, no. 4, pp. 558-564. http://dx.doi.org/10.1007/ s00128-009-9829-y. PMid:19636480.

MECHE, A., MARTINS, M.C., LOFRANO, B.E.S.N., HARDAWAY, C.J., MERCHANT, M. and VERDADE, L., 2010. Determination of heavy metals by inductively coupled plasma-optical emission spectrometry in fish from the Piracicaba River in Southern Brazil. Microchemical Journal, vol. 94, no. 2, pp. 171-174. http://dx.doi. org/10.1016/j.microc.2009.10.018.

MENDIL, D., DEMIRCI, Z., TUZEN, M. and SOYLAK, M., 2010. Seasonal investigation of trace element contents in commercially valuable fish species from the Black Sea, Turkey. Food and Chemical Toxicology, vol. 48, no. 3, pp. 865-870. http://dx.doi. org/10.1016/j.fct.2009.12.023. PMid:20036302.

MENDIL, D. and ULUOZLU, O.D., 2007. Determination of trace metal levels in sediment and five fish species from lakes in Tokat, Turkey. Food Chemistry, vol. 101, no. 2, pp. 739-745. http://dx.doi.org/10.1016/j.foodchem.2006.01.050.

MORGANO, M.A., RABONATO, L.C., MILANI, R.F., MIYAGUSKU, L. and QUINTAES, K.D., 2014. As, Cd, Cr, Pb and $\mathrm{Hg}$ in seafood species used for sashimi and evaluation of dietary exposure. Food Control, vol. 36, no. 1, pp. 24-39. http:// dx.doi.org/10.1016/j.foodcont.2013.07.036. 
NASCIMENTO, I.R., JESUS, R.M., SANTOS, W.N.L., SOUZA, A.S., FRAGOSO, W.D. and REIS, P.S., 2010. Determination of the mineral composition of fresh bovine milk from the milk-producing areas located in the State of Sergipe in Brazil and evaluation employing exploratory analysis. Microchemical Journal, vol. 96, no. 1, pp. 37-41. http://dx.doi.org/10.1016/j.microc.2010.01.010.

NIEDZIELSKI, P., RUDNICKA, M., WACHELKA, M., KOZAK, L., RZANY, M., WOZNIAK, M. and KASKOW, Z., 2016. Seleniumspecies in selenium fortified dietary supplements. Food Chemistry, vol. 190, pp. 454-459. http://dx.doi.org/10.1016/j. foodchem.2015.05.125. PMid:26212996.

OLMEDO, P., HERNÁNDEZ, A.F., PLA, A., FEMIA, P., NAVASACIEN, A. and GIL, F., 2013. Determination of essential elements (copper, manganese, selenium and zinc) in fish and shellfish samples. Risk and nutritional assessment and mercury-selenium balance. Food and Chemical Toxicology, vol. 62, pp. 299-307. http://dx.doi.org/10.1016/j.fct.2013.08.076. PMid:24007738.

OMAR, W.A., SALEH, Y.S. and MARIE, M.S., 2014. Integrating multiple fish biomarkers and risk assessment as indicators of metal pollution along the Red Sea coast of Hodeida, Yemen Republic. Ecotoxicology and Environmental Safety, vol. 110, pp. 221-231. http://dx.doi.org/10.1016/j.ecoenv.2014.09.004. PMid:25261609.

SANTOS, J.S., SANTOS, M.L.P. and CONTI, M.M., 2010. Comparative study of metal contents in Brazilian coffees cultivated by conventional and organic agriculture applying principal component analysis. Journal of the Brazilian Chemical Society, vol. 21, no. 8, pp. 1468-1476. http://dx.doi.org/10.1590/S010350532010000800009 .

SILVA, E., VIANA, Z.C.V., ONOFRE, C.R.E., KORN, M.G.A. and SANTOS, V.L.C.S., 2016. Distribution of trace elements in tissues of shrimp species Litopenaeus vannamei (Boone, 1931) from Bahia, Brazil. Brazilian Journal of Biology $=$ Revista Brasileira de Biologia, vol. 76, no. 1, pp. 194-204. http://dx.doi. org/10.1590/1519-6984.17114.
SØRMO, E.G., CIESIELSKI, T.M., ØVERJORDET, I.B., LIERHAGEN, S., EGGEN, G.S., BERG, T. and JENSSEN, B.M., 2011. Selenium moderates mercury toxicity in free-ranging freshwaterfish. Environmental Science \& Technology, vol. 45, no. 15 , pp. 6561-6566. http://dx.doi.org/10.1021/es200478b. PMid:21675723.

TÜRKMEN, M., TÜRKMEN, A., TEPE, Y., TÖRE, Y. and ATES, A., 2009. Determination of metals in fish species from Aegean and Mediterranean seas. Food Chemistry, vol. 113, no. 1, pp. 233-237. http://dx.doi.org/10.1016/j.foodchem.2008.06.071.

TUZEN, M., 2009. Toxic and essential trace elemental contents in fish species from the Black Sea, Turkey. Food and Chemical Toxicology, vol. 47, no. 8, pp. 1785-1790. http://dx.doi.org/10.1016/j. fct.2009.04.029. PMid:19406195.

UYSAL, K., KÖSE, E., BÜLBÜL, M., DÖNMEZ, M., ERDOGAN, Y., KOYUN, M., OMEROGLU, C. and OZMAL, F., 2009. The comparison of heavy metal accumulation ratios of some fish species in Enne Dame Lake (Kütahya). Environmental Monitoring and Assessment, vol. 157, no. 1-4, pp. 355-362. http://dx.doi. org/10.1007/s10661-008-0540-y. PMid:18843546.

VIANA, Z.C.V., SILVA, E., FERNANDES, G.B., KORN, M.G.A. and SANTOS, V.L.C.S., 2012. Estudo da absorção de elementos químicos no músculo de peixes do litoral da Bahia. Revista de Ciências Médicas e Biológicas, vol. 11, pp. 27-34.

VIANA, Z.C.V., SILVA, E., FERNANDES, G.B. and SANTOS, V.L.C.S., 2013. Composição centesimal em músculo de peixes no litoral do estado da Bahia/ Brasil. Revista de Ciências Médicas e Biológicas, vol. 12, pp. 155-160.

YAP, C.K., EDWARD, F.B. and TAN, S.G., 2010. Similarities and differences of metal distributions in the tissues of molluses by using multivariate analyses. Environmental Monitoring and Assessment, vol. 165, no. 1-4, pp. 39-53. http://dx.doi.org/10.1007/ s10661-009-0925-6. PMid:19452255. 